\title{
The effect of increased levels of lead in serum on several antioxidants parameters assed among workers from a large private electrical generator company
}

\author{
Wesen Adel Mehdi a,* and Atheer Awad Mehde b \\ a Department of Chemistry, College of Sciences for Women, University of Baghdad, 10070, Baghdad, Iraq \\ b Department of Acceptable Analysis, Health and Medical Technical College, 10047, Baghdad, Iraq \\ ${ }^{*}$ Corresponding author at: Department of Chemistry, College of Sciences for Women, University of Baghdad, 10070, Baghdad, Iraq. \\ Tel.: +964.770.3942699. Fax: +964.770.3942699. E-mail address: waadmwa@yahoo.com (W.A. Mehdi).
}

\section{ARTICLE INFORMATION}

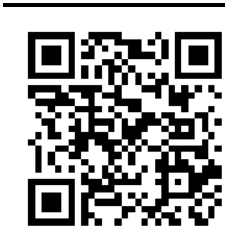

DOI: 10.5155/eurjchem.5.3.526-528.1076

Received: 18 April 2014

Received in revised form: 29 May 2014

Accepted: 31 May 2014

Online: 30 September 2014

\section{KEYWORDS}

\section{GSH}

MDA

Lead

AOPP

Vitamin C

Gases of electric generators

\section{Introduction}

Diesel generators, which are second hand in the living lodgings when electricity is cut off. Generators provide nearly all of the power for electric power grids. The reverse conversion of electrical energy into mechanical energy is done by an electric motor, and motors and generators have many similarities. Many motors can be mechanically driven to generate electricity and frequently make acceptable generator [1].

To protect the cells and organ systems of the body against reactive oxygen species, humans have evolved a highly sophisticated and complex antioxidant protection system [2].

In general, an antioxidant in the body may work at three different levels: (a) prevention-keeping formation of reactive species to a minimum e.g. desferrioxamine (b) interceptionscavenging reactive species either by using catalytic and noncatalytic molecules e.g. ascorbic acid, $\alpha$-tocopherol and (c) repair repairing damaged target molecules e.g. glutathione [3].

The advanced oxidation protein products (AOPPs) are proteins, predominantly albumin and its cumulative damaged by oxidative stress [4]. The AOPPs are one of the biochemical parameters indicative of oxidation stress. Its concentration closely correlates with the level of dityrosine, a hallmark of oxidized protein. Therefore, AOPP have been considered as the markers of oxidant-mediated protein injury [5]. Malondialdehyde, in fact, is not only an end-product of lipid peroxidation, but also the oxidative product of amino acids, carbohydrates, and DNA. Both radiation- and iron-induced oxidative damage can make MDA to be produced from free amino acids. Oxidant-induced DNA strand breakage is accompanied by release of thiobarbituric acid reactive compounds, including MDA [6]. Total antioxidant activity (TAA) consists of all antioxidants present in body fluids [7]. The total antioxidant activity is the measure of the moles of a given free radical scavenged by a test solution. Although the terms 'antioxidant capacity' and 'antioxidant activity' are often used interchangeably, their actual meanings are quite distinct [8]. Classically, "lead poisoning" or "lead intoxication" has been defined as exposure to high levels of lead typically associated with severe health effects [9]. Poisoning is a pattern of symptoms that occur with toxic effects from mid to high levels of exposure; toxicity is a wider spectrum of effects, including subclinical ones (those that do not cause symptoms) [9].

However, professionals often use "lead poisoning" and "lead toxicity" interchangeably, and official sources do not always restrict the use of "lead poisoning" to refer only to symptomatic effects of lead [9]. 
Table 1. The biochemical parameters in fifty large private electrical generators workers (Group A) and 40 normal men (Group B).

\begin{tabular}{|c|c|c|c|}
\hline Characteristic & Group A $(n=50)$ & Group B $(n=40)$ & $p$ value \\
\hline S. Lead $(\mu \mathrm{g} / \mathrm{dL})$ & $15.75 \pm 0.90$ & $3.39 \pm 0.05$ & $<0.001$ \\
\hline R.S.G. (mmol/L) & $4.33 \pm 0.85$ & $4.52 \pm 0.52$ & $>0.05$ \\
\hline S. Protein (g/dL) & $7.00 \pm 1.09$ & $7.85 \pm 0.92$ & $<0.05$ \\
\hline MDA (nmol/mL) & $3.06 \pm 0.39$ & $1.46 \pm 0.23$ & $<0.05$ \\
\hline S. TAA (mmol/L) & $0.93 \pm 0.19$ & $1.83 \pm 0.40$ & $<0.001$ \\
\hline $\mathrm{AOPP}(\mathrm{ng} / \mathrm{dL})$ & $108.11 \pm 38.21$ & $60.23 \pm 19.09$ & $<0.001$ \\
\hline Vitamin C $(\mathrm{mg} / \mathrm{dL})$ & $1.48 \pm 0.17$ & $2.21 \pm 0.28$ & $<0.01$ \\
\hline $\mathrm{GSH}(\mathrm{mg} / \mathrm{dL})$ & $34.22 \pm 6.14$ & $62.815 \pm 9.33$ & $<0.001$ \\
\hline
\end{tabular}

Table 2. Correlation between serum lead with MDA, TAA, AOPP, Vitamin C and GSH in Group A (Large private electrical generators workers).

\begin{tabular}{lll}
\multicolumn{2}{l}{ Table 2. Correlation between serum lead with } & \multicolumn{2}{l}{ Serum lead $(\boldsymbol{\mu g} / \mathbf{d L})$} & Significant $(2$-tailed) \\
\cline { 2 - 3 } & Pearson correlation & NS \\
\hline R.S.G. $(\mathrm{mmol} / \mathrm{L})$ & 0.08 & $\mathrm{NS}$ \\
S. Protein $(\mathrm{g} / \mathrm{dL})$ & 0.04 & 0.01 \\
MDA $(\mathrm{nmol} / \mathrm{mL})$ & 0.77 & 0.01 \\
S. TAA $(\mathrm{mmol} / \mathrm{L})$ & -0.82 & 0.01 \\
AOPP $(\mathrm{ng} / \mathrm{dL})$ & 0.83 & 0.01 \\
Vitamin C $(\mathrm{mg} / \mathrm{dL})$ & -0.72 & 0.01 \\
GSH $(\mathrm{mg} / \mathrm{dL})$ & 0.80 & \\
\hline
\end{tabular}

The aim of the present study is to evaluate the effect of gases rising from electric generators on Iraqi workers employed on the operation of diesel generators particularly increased lead poisoning symptoms such as muscle weakness irritability, headaches, fatigue, difficulty sleeping, difficulty concentrating, stomach pain, constipation, vomiting, nausea, anemia, unusual paleness, kidney function disorder, and loss of appetite on some biochemical parameters.

\section{Experimental}

Blood samples were collected from 50 Iraqi workers employed on the operation of diesel generators $(35.47 \pm 5.29$ years) comparing with 40 male healthy $34.80 \pm 4.28$ years. The medical history was taken, none of these patients received antioxidant medicines or foods. The blood was allowed to clot for 10-15 min. at room temperature, centrifuged for $10 \mathrm{~min}$ at $3000 \mathrm{rpm}$. Serum was removed and was divided into two parts the first to measure the biochemical parameters and the other part was stored at $-18{ }^{\circ} \mathrm{C}$ until the time of AOPP assay. Serum total protein was determined by Lowry et. al. method [10] using bovine serum albumin (BSA) as a standard protein. Total antioxidant activity (TAA) in serum samples was carried out according to Rice-Evans and Miller [11]. Plasma malondialdehyde (MDA) was determined according to the modified method of Satoh [12]. Ascorbic acid levels were estimated by the method of Tietz [13]. Glutathione (GSH) was estimated by the method of Beutler's method [14]. Serum glucose was measured by using Randox kit. Serum Lead was measured by atomic absorption spectrometry. The serum AOPP was measured by Enzyme Linked Immunosorbent Assay (ELISA) (Cusabio Biotech Com.)

All statistical analysis in the study was performed using SPSS version 19.0 for Windows (Statistical Package for Social Science, Inc., Chicago, IL, USA). Descriptive analysis was showed the mean and standard deviation of variables. The significance of differences between mean values was evaluated by Student $t$-test. The probability $p<0.05$ was considered statistically significant, while $p>0.05$ was referred to statistically insignificant. Correlation analysis was used to test the linear relationship between the factors. ANOVA test was used to confirmation the differences between variables of different groups.

\section{Results and discussion}

The results were observed as follows of fifty large private electrical generators workers (Group A), forty normal men (Group B) were serve as control group shown in Table 1.
There were significant positive correlations between serum lead with MDA, TAA, AOPP, and negative significant with vitamin C, GSH in Group A (large private electrical generators workers) as shown in Table 2. As our knowledge no previous study referred to these correlations.

The present study showed that lead is a persistent toxic metal and associated with impairment of various body functions in workers employed on the operation of diesel generators. Oxidative stress has been reported such as one of the significant mechanism of toxic effect of lead [15,16]. It is suggested that the alterations in glutathione as well as antioxidant enzyme activities implicate oxidative stress in the toxicity of lead. Acute and chronic loud noise contact generates extreme free radicals and reason disorders that involve extraauditory body part such as neural cells, endocrine functions and cardiovascular homeostasis [17]. Accumulation of AOPPs has been described in many pathologie [18-20], also those connected with impaired carbohydrate metabolism [18,21]. These products create as a result of the action of free radicals on proteins and may act as inflammatory mediators triggering the oxidative "ignition" of neutrophiles, monocytes and T lymphocytes thus leading to up regulation and excessive motivation of dendritic cells [22].

The correlation in Table 2 between serum lead and antioxidant parameters referred to harmful effect to direct contact to gasses from Diesel Generators on workers employed on the operation on it.

\section{Conclusion}

The current study recommends that the Ministry of Health (Iraq) should inform all owners of the industrial factories and electrical generators about the harmful effects of the gasses from generators on human health. Furthermore, the number of resting days, as a recovery period, must be 7-10 days per month for all workers who are working in such nuisance environment.

\section{References}

[1]. Goudarzi, N. A. Int. J. Dynam. Cont. 2013, 1(2), 192-202.

[2]. Jacob, R. A. Nutr. Res. 1995, 15(5), 755-766.

[3]. Amit, K.; Priyadarsini, K. I. Med. Allied. Sci. 2011, 1(2), 53-60.

[4]. Kalousova, M.; Zima, T.; Tesar, V.; Dusilova-Sulkova, S.; Skrha. J. Mutat Res. 2005, 579, 37-46.

[5]. Zhou, Q.; Wu, S.; Jiang, J.; Tian, J.; Chen, J.; Yu, X.; Chen, P.; Mei, C.; Xiong, F.; Shi, W.; Zhou, W.; Liu, X.; Sun, S.; Xie, D. I.; Liu, J.; Xu, X.; Liang, M.; Hou, F. Nephrology 2012, 17(7), 642-649.

[6]. Long, J.; Liu, C.; Sun, L.; Gao, H.; Liu, L. J. Neurochem. Res. 2009, 34(4), 786-794. 
[7]. Krawczuk-Rybak, M.; Panasiuk, A.; Czygier, M.; Muszynska-Roslan, K.; Wysocka, J.; Szmitkowski, M. Folia Histochem. Cytobiol. 2012, 50(3), 468-472.

[8]. Caylak, E; Halifeoglu, I; Aydin, S; Telo, S; Bulmus, O; Celik, H. Turkiye Klin. J. Med. Sci. 2007, 27(6), 823-828.

[9]. Caylak E, Halifeoglu I. Cocuk Sag. Hast. Derg. 2010, 53(2), 159-173.

[10]. Lowry, N. J.; Rosebrough, A. I.; Randal, L. R. J. Biol. Chem. 1951, 193, 265-275.

[11]. Mehdi, W. Aust. J. Basic Appl. Sci. 2011, 5(8), 196-203.

[12]. Satoh, K. Clin. Chim. Acta. 1978, 90, 37-43.

[13]. Tietz, N. W. Text book of clinical chemistry, Saunders Company, Philadelphia, London, Toronto, pp. 960-962, 1986.

[14]. Beutler, E.; Duron, O.; Kelly, B. M. J. Lab. Clin. Med. 1963, 61, 882-888.

[15]. Caylak, E.; Aytekin, M.; Halifeoglu, I. Exp. Toxicol. Pathol. 2008, 60(45), 289-294.

[16]. Caylak, E; Halifeoglu, I. Turkiye Klin. J. Med. Sci. 2007, 27(1), 1-8.

[17]. Demirel, R.; Mollaoglu, H.; Yesilyurt, H.; Ucok, K.; Aycicek, A.; Akkaya, M. Eur. J. Gen. Med. 2009, 6(1), 20-24.

[18]. Krzystek-Korpacka, M.; Patryn, E.; Boehm, D.; Berdowska, I.; Zielinski, B.; Noczynska, A. Clin. Biochem. 2008, 41(12), 943-949.

[19]. Zhou, L. L.; Cao, W.; Xie, C.; Tian, J.; Zhou, Z.; Zhou, Q.; Zhu, P.; Li, A.; Liu, Y.; Miyata, T.; Hou, F. F.; Nie, F. J. Kidney Int. 2012, 82(7), 759-770.

[20]. Kosova, F.; Cetin, B.; Akinci, M.; Aslan, S.; Ari, Z.; Sepici, A.; Altan, N.; Cetin, A. Ann. Surg. Oncol. 2007, 14(9), 2616-2620.

[21]. Piwowar, A.; Knapik-Kordecka, M.; Warwas, M. Diabetes Res. Clin. Pract. 2007, 77, 188-192.

[22]. Skvarilova, M.; Bulava, A.; Stejskal, D.; Adamovska, S.; Bartek, S. J. Biomed. Pap. Med. Fac. 2005, 149(1), 83-87. 